\title{
Relationship between snowdrift development and drifted snow during a wind episode
}

\author{
M. Mases, ${ }^{1}$ D. Font, ${ }^{2}$ J. M. Vilaplana ${ }^{2}$ \\ ${ }^{1}$ ICC. Servei Geologic de Catalunya, Parc de Montjuic s/n, 08038 Barcelona, Spain \\ ${ }^{2}$ Departament de Geologia Dinàmica, Geofísica i Paleontología, Universitat de Barcelona, 08071 Barcelona, Spain
}

\begin{abstract}
Snowdrift formation has been monitored in the eastern Spanish Pyrenees since 1992 at an experimental study plot at the La Molina ski resort between 2000 and $2400 \mathrm{~m}$. Several instruments were installed to characterize the wind, quantify snowmass flux, detect snowdrifting episodes and measure the evolution of a natural snowdrift.

This plot is situated within a natural snowdrift and is equipped with measuring instruments such as snow poles, three columns of snow collectors (prismatic boxes) facing the dominant winds and an anemographic station.

During the 4 years of data acquisition, the thickness of the snowdrift has been measured and the snow collectors checked once each week. An active interest has been taken in the relationship between snowdrift development and drifting snow during a wind episode.

The relationship observed between wind, drifting snow and the development of the snowdrift is presented. The results show: (1) the amount of snow collected in the snow collectors is related to wind intensity and to the availability and the quality of drifting snow, and (2) wind intensity principally affects the relative location of maximum snowdrift growth rather than controlling the thickness of the snowdrift.

By comparing the evolution of the snowdrift with Tabler's (1975) model, we observed that it fits with the topographic features of our study area for the three seasons shown.
\end{abstract}

\section{INTRODUGTION}

Human activities are often threatened by snowdrifting. In our area this occurs principally in high mountain environments. Wind episodes distribute the snow irregularly, producing accumulation areas that increase the avalanche hazard.

Snowdrifting also affects the road and railway network, producing disturbances in both and increasing danger to traffic due to reduced visibility.

In ski resorts the effects of the wind on open areas are reflected in the erosion of snow from ski runs, causing important economic losses.

Snowdrifting has often been studied from its theoretical point-of-view (Kobayashi, 1972; Martinez, 1996; Naaim-

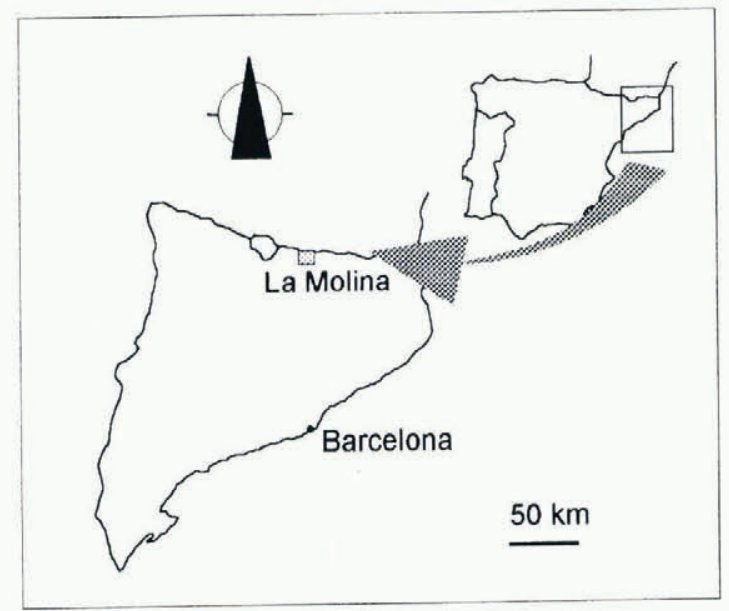

Fig. 1. The study area.
Bouvet and Naaim, 1995). However, few of these studies have been undertaken in high mountain areas with complicated relief (Castelle, 1990; Duclos, 1993; Mases and Vilaplana, 1994; Mases and others, 1995).

An experimental plot has been equipped in the eastern Spanish Pyrenees on the highest slopes of the La Molina ski resort. Working in a ski area considerably simplifies access to the site in all weather conditions.

This paper describes the gauges used at the La Molina plot, the measurements done, the type of data obtained and the results inferred from these with respect to the distribution of snow in a natural snowdrift.

\section{STUDY AREA}

The experimental site is on the highest slopes (Torrent Negre) of the La Molina ski resort in the Catalan Pyrenees, in northeastern Spain (Fig. 1). It is accessible by skilift.

The Torrent Negre area is characterized by high erosion surfaces or platforms and by a flat topography. However, there are some slope changes that produce snowdrifts. At one of these snowdrifts have been monitored. The gauges are installed in this area.

The altitude range in the study area is between 2000 and $2400 \mathrm{~m}$ on a slope mainly exposed to the north. Mean annual precipitation is about $1211.2 \mathrm{~mm}$ of water; mean annual snow precipitation is about $414 \mathrm{~mm}$ of water and the average snow-accumulation thickness is about $2.5-3 \mathrm{~m}$ at $2050 \mathrm{~m}$. Precipitation comes mainly from the east and is often followed by strong north winds that immediately redistribute all the fresh snow. The snow lies on the ground 
about 137 days per year at $1711 \mathrm{~m}$. The mean annual temperature is about $5.4^{\circ} \mathrm{C}$, and the February average temperature is about $-1.6^{\circ} \mathrm{C}$ (Salvador, 1985 ).

Wind is characterized by high-intensity episodes that come from the north and northwest. Precipitation comes mainly from the east and is often followed by strong north winds that immediately redistribute all fresh snow.

\section{EXPERIMENTAL EQUIPMENT}

Several gauges were installed to measure wind episodes and the resulting redistribution of snow during the 1992-93, 1993 -94, 1994- 95 and 1995-96 seasons. They were the following:

Wind vane and wind-speed sensor with digital registration. It provides a continuous record throughout the snow season with a sampling time of 2 minutes. It was situated $11 \mathrm{~m}$ high on a skilift tower near the other gauges.

Snow-collector columns. These are boxes that collect a sample of the snow transported during a wind episode. Their capacity is 401 and they are piled up in columns of six collectors. Blowing snow is collected at six different heights $(0.26,0.52,0.78,1.04,1.30$ and $1.56 \mathrm{~m}$ above the ground).

Monitored snowdrift. This formed during northerly and northwesterly episodes. It was equipped with two lines of seven poles, one line oriented north-south and the other northwest ${ }^{-}$southeast. The poles have lengths of 3 and $5 \mathrm{~m}$ and were graduated every $0.10 \mathrm{~m}$.

The poles in the snowdrift were measured once a week. The snow collectors were sampled once a week and immediately after snowdrifting occurred, when the snow collected was weighed.

Different measurements were also made on the snowpack. Once a week a snow-stratigraphy profile was done and each day weather conditions were measured and the type of snow on the surface recorded.

These data allowed us to characterize the episodes of snow transport. Following the data analysis, we consider that a wind episode begins when the speed exceeds $6 \mathrm{~m} \mathrm{~s}^{-1}$; below this snowdrifting very seldom occurs.

\section{COMPARISON BETWEEN DRIFTED SNOW AND THE DEVELOPMENT OF A SNOWDRIFT}

Measurements on the poles indicated the evolution of the thickness of the snowdrift.

In Figure 2 the snowdrift evolution on a north south orientation for the 1992-93 season is shown. The snowdrift grew slowly until the end of February. On the 26 February 1993 an important increase was observed, and also at the next measurement on 9 March 1993. From mid-March until 27 April snow loss was the main process in the snowdrift. This loss could be produced either by melting or by winds redistributing the snow.

From interpretation of the profiles obtained during the last three seasons we observed:

A snowdrift goes through several evolutionary stages.

These stages are related to the number of snowdrifting episodes that occur. During winter, the rate of growth

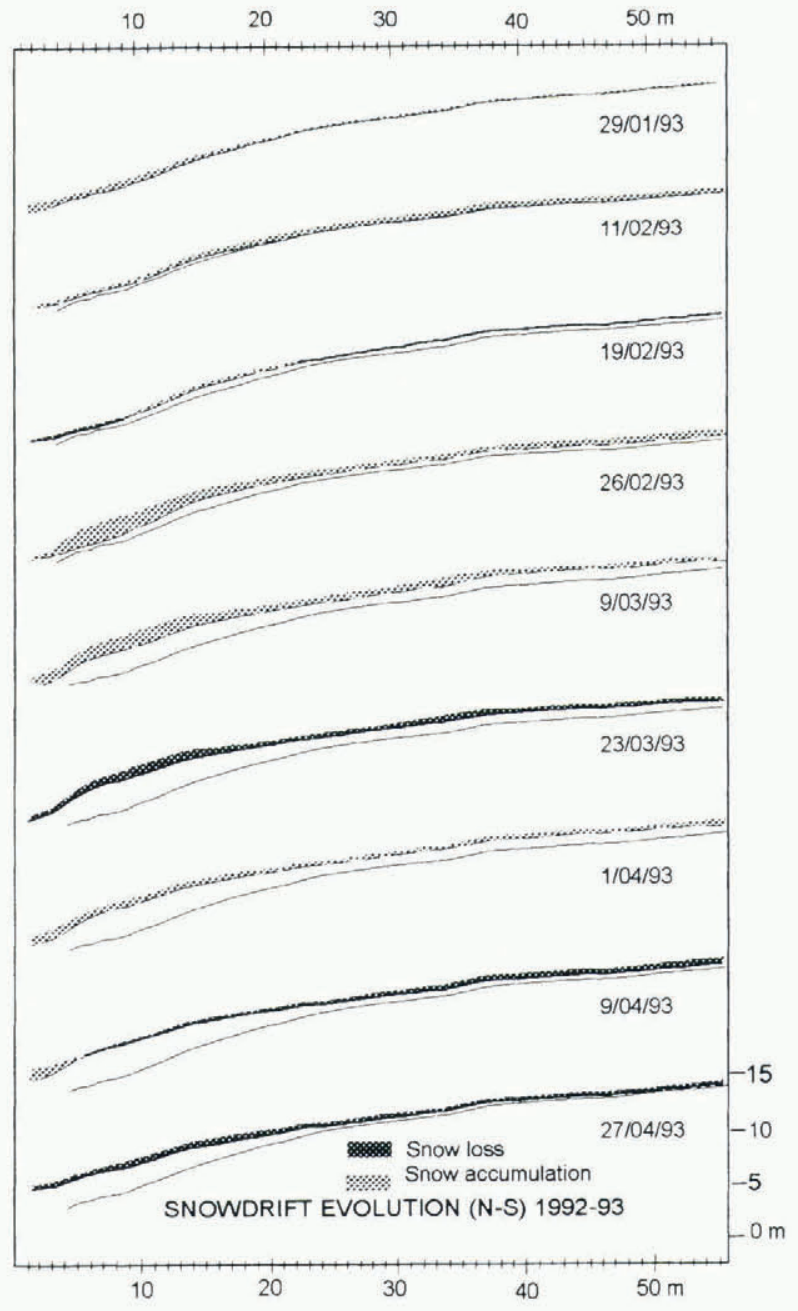

Fig. 2. Snowdrift evolution (north-south) orientation during the 1992-93 season.

of a snowdrift is directly related to the number of snowdrifting events.

The maximum growth of the snowdrift occurred during the early wind episodes of the season.

Variations of snow height were more important during the early episodes of the season than during the later ones.

A comparison between volume variations of the snowdrift and the snow transported by the wind would be of great interest. Distances between the poles in the snowdrift were too great to calculate the total volume of the snowdrift. In order to discover the growth and changes in the snowdrift thickness, an imaginary vertical plane through the two lines of snow poles was used to calculate surface variations. These surface changes are representative of the volume variations in the snowdrift (Fig. 3).

In Figure 4, the number of episodes (snowdrifting events) vs the variations $\left(\mathrm{m}^{2}\right.$; Fig. 3$)$ of the snowdrift thickness for each wind episode is presented for the 1992-93 and 1993-94 seasons. The first two snowdrifting episodes during a winter season are those that produce the most important increase in area (Fig. 3). However, loss of snow due to a wind episode from the opposite direction or high temperatures, producing a decrease in the snow-cover thickness by melting, changes the snowdrift profile and thus the evolutionary stage of the snowdrift.

Tabler (1975) pointed out that the increase of snow in a 


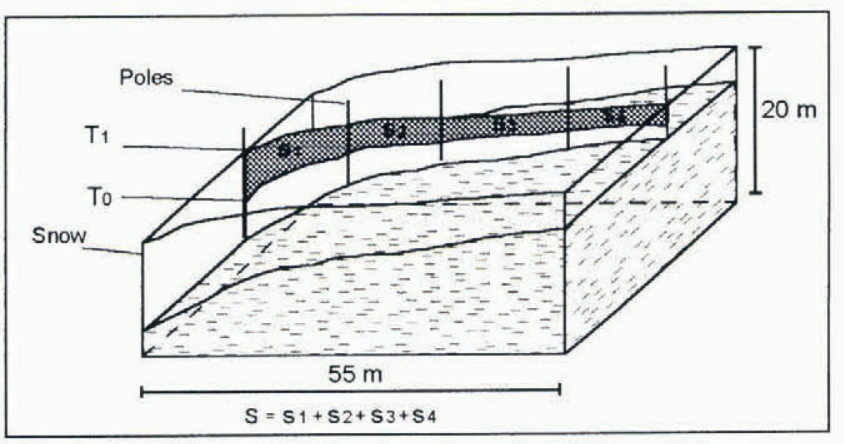

Fig. 3. An imaginary vertical plane through the lines of poles allows us to calculate surface variations. $T_{0}=$ Time 0 (before a snow-drifting event) and $T_{1}=$ Time 1 (after the snow-drifting event). $S=$ total increase in $m^{2}$ of the snowdrift in one of the lines (northwest-southeast or north-south).

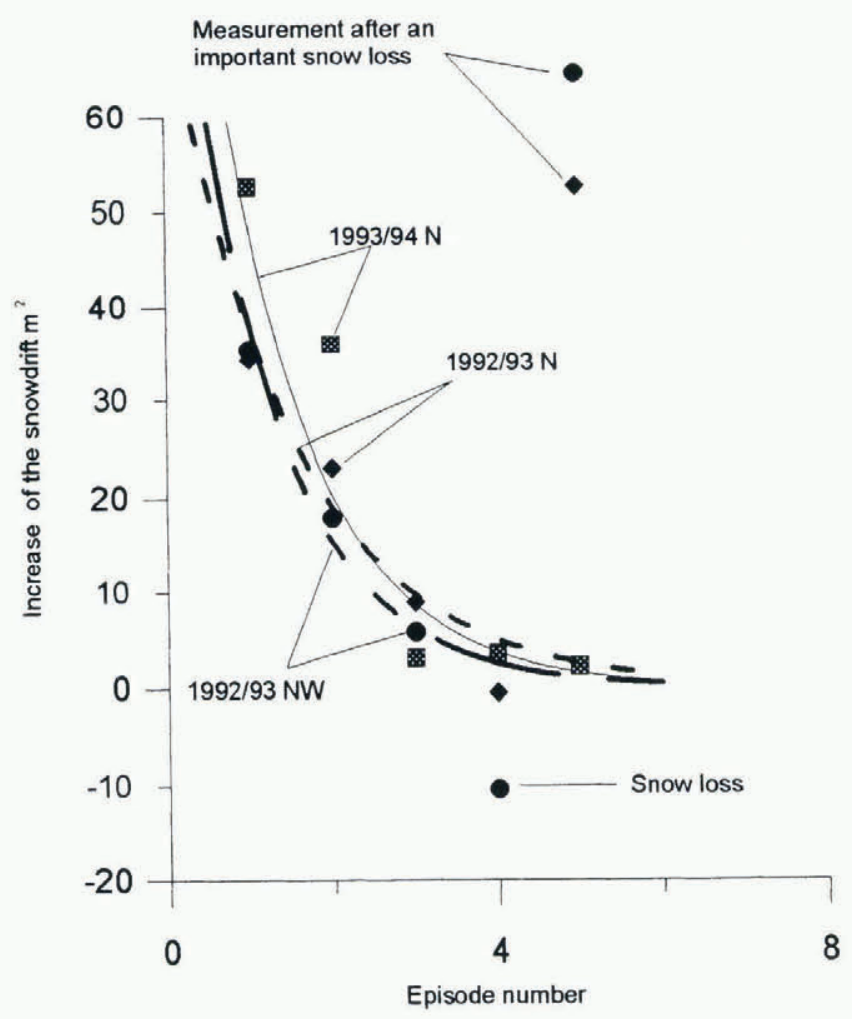

Fig. 4. The number of episodes (snowdrifting events) vs variations of the snowdrift thickness $\left(\mathrm{m}^{2}\right)$. Refer to Figure 3. Lines are fit to the data. Seasons of 1992-93 and 1993-94 for the north-south line are plotted.

snowdrift is inversely proportional to the amount of snow accumulated. The efficiency of snow trapping from a slope change (snowdrift) decreases while the natural snowdrift is being built. This is what was observed at the La Molina snowdrift during the 1992-93, 1993-94 and 1994-95 seasons.

Table 1 shows the amount of snow collected in the two snow-collector columns (oriented north and northwest), the growth of the snowdrift (Fig. 3) and the main meteorological parameters (wind velocity, air temperature, snowgrain types and the occurrence of precipitation).

The wind episodes of 28 December, 1 April 1993 and 22 April 1994 show similar features. The air temperature ranged between $3^{\circ}$ and $-20^{\circ} \mathrm{C}$ during the three episodes. While snowdrifting occurred there was precipitation during the three episodes and the amount of available snow to be
Table 1. Description of episodes

\begin{tabular}{|c|c|c|c|}
\hline & $28 \mathrm{Dec} 1993$ & I Apr 1993 & 22.4 pr 1.994 \\
\hline Snowdrift growth north & $64.8 \mathrm{~m}^{2}$ & $5.75 \mathrm{~m}^{2}$ & $10.35 \mathrm{~m}^{2}$ \\
\hline $\begin{array}{l}\text { Snowdrift growth } \\
\text { northwest }\end{array}$ & $52.6 \mathrm{~m}^{2}$ & $8.85 \mathrm{~m}^{2}$ & $13.2 \mathrm{~m}^{2}$ \\
\hline $\begin{array}{l}\text { Snow collected in snow } \\
\text { collectors }\end{array}$ & $3350 \mathrm{~g}$ & $3430 \mathrm{~g}$ & $3505 \mathrm{~g}$ \\
\hline $\begin{array}{l}\text { Snow collected in snow } \\
\text { collectors northwest }\end{array}$ & $2525 \mathrm{~g}$ & $1825 \mathrm{~g}$ & $1825 \mathrm{~g}$ \\
\hline Total of snow collected & $5875 \mathrm{~g}$ & $525.5 \mathrm{~g}$ & $5330 \mathrm{~g}$ \\
\hline Maximum velocity & $38.4 \mathrm{~m} \mathrm{~s}^{\prime}$ & $28.4 \mathrm{~m} \mathrm{~s}$ & $52.1 \mathrm{~ms}$ \\
\hline Average velocity & $8.2 \mathrm{~ms}^{1}$ & $9.4 \mathrm{~ms} \mathrm{~s}^{1}$ & $5.8 \mathrm{~ms}^{\prime}$ \\
\hline Snow on surface & $\begin{array}{l}\text { Rounded } \\
\text { particles }\end{array}$ & $\begin{array}{l}\text { Fragmented } \\
\text { particles }\end{array}$ & $\begin{array}{c}\text { Fragmented } \\
\text { particles }\end{array}$ \\
\hline Precipitation & $0.63 \mathrm{~m}$ & $0.22 \mathrm{~m}$ & $0.21 \mathrm{~m}$ \\
\hline Temperature max./min. & $4 /-21 \mathrm{C}$ & $3 /-14 \mathrm{C}$ & $3 /-13 \mathrm{C}$ \\
\hline
\end{tabular}

drifted away was also similar. Wind velocities were similar during the first two episodes, above $25 \mathrm{~m} \mathrm{~s}^{-1}$, but during the third one the velocity was much higher. The snow-collector columns collected $5875 \mathrm{~g}$ during the first episode, $5255 \mathrm{~g}$ during the second and $5330 \mathrm{~g}$ during the third. This indicates that the quantity of drifted snow was also very similar during the three episodes. However, during the 28 December 1993 episode the snowdrift grew $64.8 \mathrm{~m}^{2}$ in the northerly direction and $52.6 \mathrm{~m}^{2}$ in the northwesterly direction. During the 4 January 1993 episode, the growth was $5.75 \mathrm{~m}^{2}$ and $8.85 \mathrm{~m}^{2}$ and in the 22 April 1994 episode it was $10.35 \mathrm{~m}^{2}$ and $13.2 \mathrm{~m}^{2}$, respectively in the northerly and northwesterly direction (Fig. 3 and Table 1). The differences found by comparing these three episodes are assumed to be different stages of evolution between the first case and the other two. The second and third episodes represent similar evolutionary stages, in both cases the snowdrift was approaching its equilibrium profile (Tabler, 1975).

Snowdrifting episodes with similar features produce different rates of growth in a snowdrift depending on its evolutionary stage. We have assumed that the amount of transported snow is not the main control during snowdrift evolution.

Considering the proximal zone (windward area), and the distal zone (leeward area), of the snowdrift, it is in the distal zone where volume changes are more pronounced.

Wind intensity principally affects the relative position of the maximum rate of growth of snowdrifting. Strong winds tend to increase the volume of the snowdrift in the distal zones rather than in the proximal ones (Fig. 5).

\section{APPLICATION OF TABLER'S (1975) SNOWDRIFT- DEVELOPMENT MODEL}

Tabler (1975) developed a statistical model to predict the maximum profiles of snowdrifts. He studied their evolution in Wyoming. His model fits in flat environments but cannot be applied to high-mountain environments or to snowdrifts with high angles.

Taillandier and others (1990) proved that the same requirements are preserved while working with scale models in real conditions. The La Molina snowdrift is smaller than those studied by Tabler (1975) so to apply his model we have increased the size of our snowdrift by three times (Taillandier and others, 1990). 


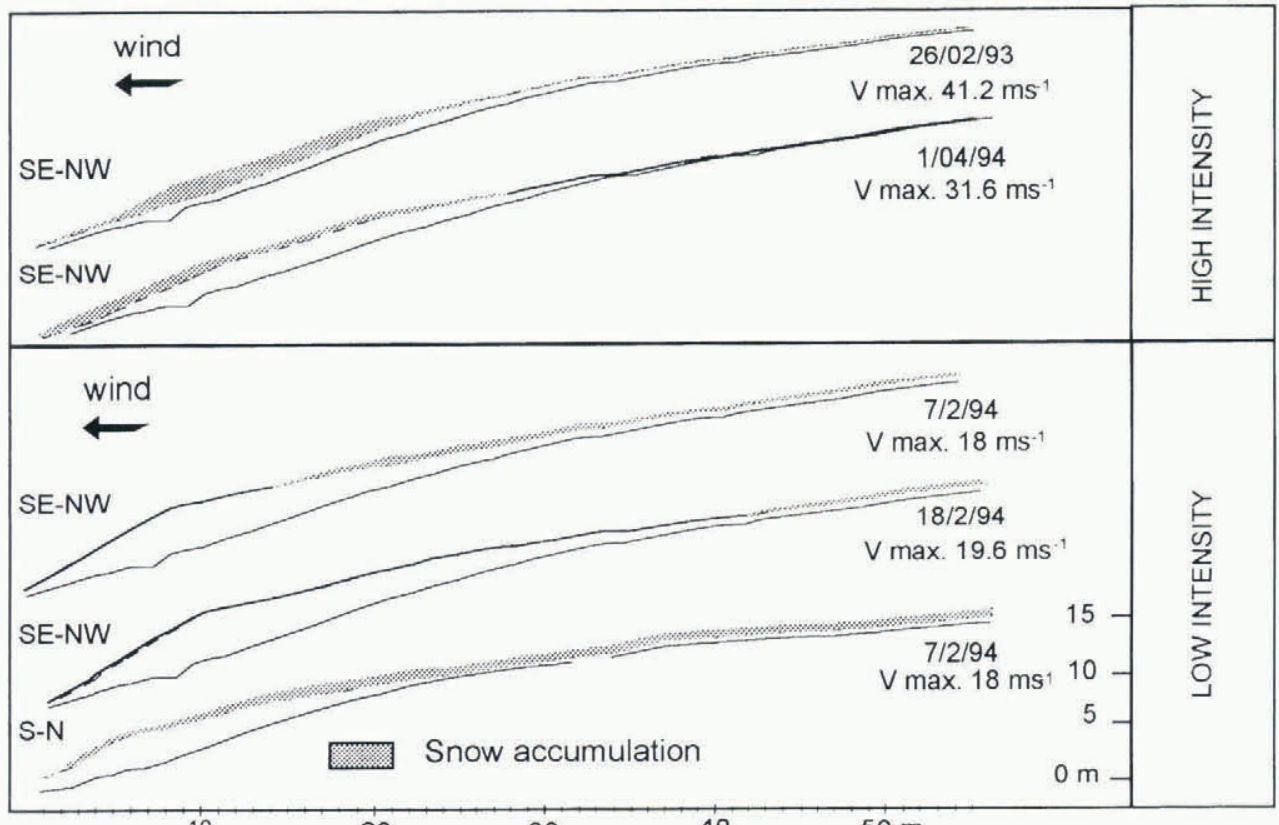

Fig. 5. Variations of snowdrift depending on the wind intensity.

In Figure 6, we show profiles derived for three seasons 1992-93, 1993-94 and 1994-95, and also the predicted profile using Tabler's model for the La Molina snowdrift. The three seasons show differences when compared with the model. In the 1992-93 season, Tabler's model fits with our snowdrift profile. In the 1993-94 season (case b), we observed that in the 11 February 1994 measurement the snowdrift presented a profile above Tabler's predicted equilibrium profile. This situation was produced by a snow-drifting episode characterized by low-intensity winds (Fig. 5).

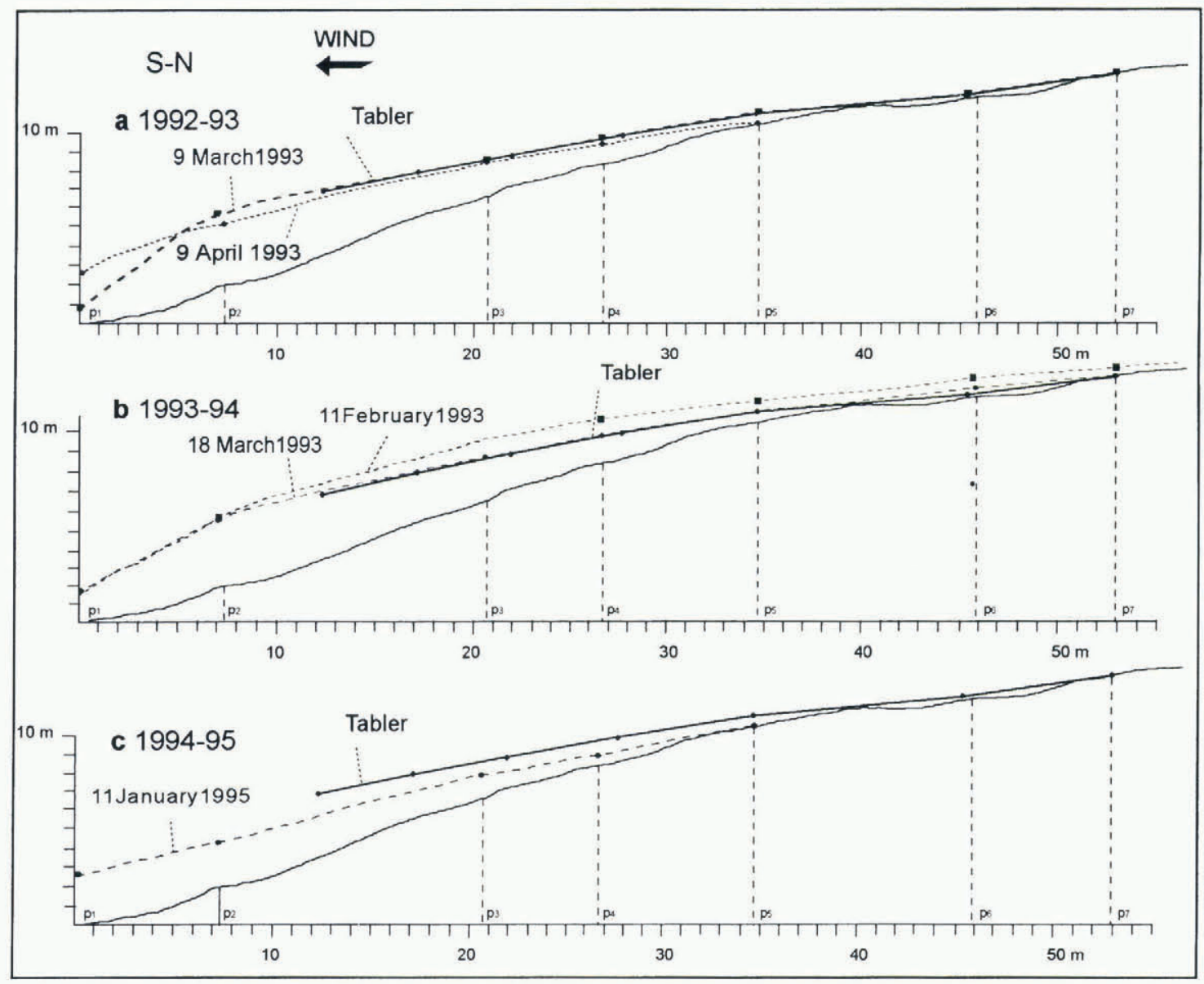

Fig. 6. Profiles of the La Molina snowdrift for the 1992 93, 1993-94 and 1994-95 seasons, compared with those predicted by Tabler's (1975) model. 
However, later episodes (18 March 1994) removed the snow that exceeded Tabler's profile and the snowdrift reached its equilibrium profile. Finally, in the 1993-94 season, the snowdrift did not reach Tabler's equilibrium profile. This season was characterized by very low precipitation rates, which meant there was little snow to be drifted. We also observed that, for the three seasons presented in Figure 6, Tabler's model fitted with the topographic features of our study area.

\section{CONCLUSIONS}

From the experimental data obtained at La Molina we observed that the factor controlling the growth of a snowdrift is its evolutionary stage. The amount of snow transported during a wind episode is not the main factor. The evolutionary stage is directly related to the number of snowdrifting episodes that had occurred previously. These observations are in agreement with those of Tabler (1975).

An identical blowing-snow event produces different rates of growth in a snowdrift depending upon whether it occurs in the initial or final stage of the evolution.

Wind velocity principally affects the location of the snow deposit, the stronger the wind velocity the further away (distal) the snow accumulates as a drift, and the lower the velocity the nearer (proximal) it accumulates.

By comparing the evolution of the snowdrift with Tabler's (1975) model we observed that for the three seasons presented it fitted with the topographic features of our study area.

\section{ACKNOWLEDGEMENTS}

This research was funded by Project AMB-0837 from the
CICYT and Project of Human Capital and Mobility of the ECC, contract No. CHRX-CT93-0307 (DG COMA). J. Dent and R. A. Schmidt led to substantial improvements in the final version of this manuscript.

We should also like to acknowledge the logistical support given by the La Molina (Ferrocarrils de la Generalitat de Catalunya) ski resort, and especially the ski-patrol team.

\section{REFERENCES}

Castelle, T., M. Roussel and A. Clappier. 1990. Transport de la neige par le vent en montagne: mesures sur site et en laboratoire, première modélisation. In Colloque Dynamique des Risques . Naturels el Glaciochimie, Décembre 5-7, 1990, Grenoble. Saint-Martin-d'Hères, 1.66-1.83.

Duclos, A. 1993. Neige, vent et avalanches: quelques observations pour un meilleur prognostic. Neiges et Avalanches 64, $21-27$.

Kobayashi, D. 1972. Studies of snow transport in low-level drifting snow. Contrib. Inst, Low Temp. Sci., Ser. A 24, 1-58.

Martinez, H. 1996. Contribution à la modélisation du transport éolien de particules. Mesures de profils de concentrations en soufflerie diphasique. (Thèse de doctorat, Université Joseph Fourier, Grenoble.

Mases, M. and J. M. Vilaplana. 1994. Estudio del transporte élico de la nieve en el Pirineo Oriental: primeros resultados. In Arnáez, J., J. M. García-Ruiz and A. Gómez Villar, eds. Geomorfología en España. Logroño, Sociedad Española de Geomorfología, 209-225.

Mases, M., L. Buisson, W. Good and J. M. Vilaplana. 1995. Étude de la répartition spatiale des effets du transport de neige par le vent: premiers travaux réalisés à partir de mesures systématiques sur le terrain. Houille Blanche, 50 5-6, 50-55.

Naaim-Bouvet. F. and M. Naaim. 1995. Modélisation physique en soufflerie et lextérieur du transport de neige par le vent. Houille Blanche, 50 (7), 68-75.

Salvador, F. 1985. Aportación al estudio nivoclimático del Pirineo Oriental. Notas de Geografía Fisica 13-14, 67 84.

Tabler, R. D. 1975. Predicting profiles of snowdrifts in topographic catchments. Proc. West. Snow Conf., 43rd Annual Meeting, 23-25 April 1975, Coronado, California, 87-97.

Taillandier, J. M., R. Verreault and G. Vachon. 1990. Essai de maquettes brise-vents dans des conditions naturelles de poudrerie au Québec. $I n-$ editor-, ed. Dynamique des risques naturels et glaciochimie; quatrième entretiens Jacques Cartier. Grenoble, CEMAGREF, $12-18$. 